\title{
Ranunculus degenii and Verbascum scardicola new records from the Restelica and Vraca valleys (NP Sharri) in Kosovo
}

\author{
Zeqir Hashani ${ }^{1}$, Qenan Maxhuni ${ }^{3}$, Lulzim Zeneli ${ }^{1}$ \& Rrahman Ferizi ${ }^{2}$ \\ ${ }^{1}$ University of Gjakova "Fehmi Agani" Str. Ismail Qemali, 50000 Gjakove, Kosovo \\ 2 University of Prishtine, Faculty of Medicine, Str. Bul. i Dëshmorëve, n.n. 10000 Prishtine, Kosovo \\ ${ }^{3}$ Kosovo Institute for Nature Protection, Str. L. Haradinaj, ex-Rilindja, 10000 Prishtine, Kosovo; \\ qmaxhuni@yahoo.com
}

\begin{abstract}
Hashani Z., Maxhuni Q., Zeneli L. \& Ferizi R. (2021): Ranunculus degenii and Verbascum scardicola new records from the Restelica and Vraca valleys (NP Sharri) in Kosovo. - Thaiszia - J. Bot. 31 (2): 195-204.

Abstract: The valleys of Restelica and Vraca in Kosovo have not been explored sufficiently due to their geographical position and the harshness of the terrain. The plant species Ranunculus degenii has been collected in Restelica, on the way to the border with North Macedonia or between this road and the Albanian border near Shishtavec, while the species Verbascum scardicola has been found in the Vraca valley. These localities are mainly dominated by silicate substrate, although the presence of conglomerate substrates is not excluded. These newly discovered habitats of these rare and endangered species represent their southernmost edge known to date. This paper reviews and discusses their discovery, description, distribution and mapping in these localities of the Sharri Mountains.
\end{abstract}

Keywords: Sharri Mountains, Kosovo flora, rare and endemic species, species distribution.

\section{Introduction}

Kosovo is located in the centre of Southeast Europe; it lies between parallels $41^{\circ} 50^{\prime} 58^{\prime \prime}$ and $43^{\circ} 51^{\prime} 42^{\prime \prime}$ of the earth's northern latitude and between the meridian $20^{\circ} 01^{\prime} 30^{\prime \prime}$ and $21^{\circ} 48^{\prime} 02^{\prime \prime}$ of eastern longitude. The total area of the territory is 10,908 $\mathrm{km}^{2}$. The distance from north to south is $147 \mathrm{~km}^{2}$ and from east to west around 154 $\mathrm{km}^{2}$, while the average altitude is $810 \mathrm{~m}$. The main relief forms are mountains - 
around $63 \%$ of the territory - and depressions, which cover around $37 \%$ of the territory. Although a small country, Kosovo is known for its rich biodiversity. This diversity probably results from its geographical position, as well as geological, pedological, hydrological, relief, climatic and other factors, all of which allow for the growth and development of rare and endemic plant taxa. Our country is also considered a refugee centre in the Balkan Peninsula, where many thermophilic floristic elements have been found in different geological periods, especially the glacial period, and preserved up to the present (Maxhuni et al. 2014; Anonymous 2008).

Based on the geological structure of the studied region, two major geomorphological groups were distinguished: carbonate rock formations (limestone, dolomite, etc.), and siliceous formations of the Paleozoic and Quaternary, located mainly in the Sharri Mountains (ICMM 2006; Shuka et al. 2008; Hoxhaj et al. 2009).

The mountains of southeastern Europe are considered areas of remarkably high plant diversity and are rich in endemic species (Väre et al. 2003). This is especially true for the Sharri Mountains, which show a high degree of heterogeneity. As a result, these mountains are rich in endemic species that have a very limited distribution in other countries in the Western Balkans.

According to the results of floral diversity surveys, the Sharri mountain range harbours over 2,000 taxa of vascular plants, including around 150 endemic taxa (Rexhepi 1986; Anonymous 2008). The Sharri Mountains, as well as some other mountain ranges in the South-Western Balkans, such as the Albanian Alps, KorabJablanica, the Tomorri Mountain, Galicica - Dry Mountain (Mts. Thate), etc., are characterised not only by a high floral diversity and richness in endemism but are also considered centres of formation of new species (Tab 1.).

The floristic register of this region identifies around 460 rare and endangered species, which represent the peculiarities of the vascular flora of the country, even though they are found only on the territory of the Dragash and Prizren Municipalities (Stefanović et al. 2003; Millaku et al. 2013; Hashani et al. 2014).

The Restelica valley extends along the Sharri Mountains, on the border between the Kallabak Mountain and North Macedonia, with an altitude of up to $2536 \mathrm{~m}$ and a heterogeneous substrate composition, where the silicate substrate predominates.

The Vraca valley is located in the south of the Sharri Mountains and is characterised by steep slopes and relief contrasts, reflecting the dominance of the Mediterranean and continental currents.

In terms of substrate composition, the valley is heterogeneous with silicate substrate predominating, while on the western side of Vraca there is also a substrate with geological limestone composition, along with the presence of some calcareous rocks of relatively large size.

These species are common in certain countries, but in general they are not widely distributed. Therefore, there is a need for scientific research into the location of these species, which would also serve as an indicator of the features of the habitats where they grow naturally. 
Tab. 1 Endangered species found in the study area and their status according to the Kosovo Red Book (Millaku et al. 2013).

\begin{tabular}{|c|c|c|c|c|c|}
\hline Endangered species & Locality & $\begin{array}{l}\text { L. } \\
\text { F. }\end{array}$ & Flor. El. & $\begin{array}{l}\text { Sub. } \\
\text { Hab. }\end{array}$ & Status \\
\hline Fritillaria macedonica Bornm. & Vraca & G & Subendemic & $\mathrm{S}$ & CR \\
\hline Verbascum scardicola Bornm. & Vraca & $\mathrm{H}$ & SEMM & $\mathrm{C} / \mathrm{S}$ & CR \\
\hline Ranunculus degenii Kümmerle et Jáv. & Restelica & $\mathrm{H}$ & Balkan & $\mathrm{C} / \mathrm{S}$ & $\mathrm{CR}$ \\
\hline Cerastium neoscardicum Niketić & Restelica & $\mathrm{Ch}$ & Endemic & $\mathrm{S}$ & CR \\
\hline Comarum palustre $\mathrm{L}$. & Vraca & G & Med & $\mathrm{C} / \mathrm{S}$ & CR \\
\hline Triglochin palustris $\mathrm{L}$. & Vraca & G & Balkan & $\mathrm{C} / \mathrm{S} / \mathrm{M}$ & CR \\
\hline Viola schariensis Erben & Restelica & $\mathrm{H}$ & Balkan & $\mathrm{C} / \mathrm{S}$ & CR \\
\hline Centaurea kotschyana Heuff. & Vraca/Restelica & $\mathrm{H}$ & Sub-Balkan & $\mathrm{C} / \mathrm{S}$ & EN \\
\hline Senecio scopolii Hope \& Hore & Restelica & $\mathrm{H}$ & Balkan & $\mathrm{C} / \mathrm{S}$ & EN \\
\hline Campanula albanica Witasek & Vraca/Restelica & $\mathrm{H}$ & Balkan & $\mathrm{S}$ & EN \\
\hline Achillea chrysocoma Friv. & Vraca & $\mathrm{H}$ & Balkan & $\mathrm{C} / \mathrm{S}$ & EN \\
\hline Potentilla doerfleri Wettst. & Vraca & $\mathrm{H}$ & CEM & $\mathrm{S}$ & EN \\
\hline $\begin{array}{l}\text { Achillea corabensis (Heimerl) } \\
\text { Micevsci }\end{array}$ & Vraca & $\mathrm{H}$ & Balkan & $\mathrm{C}$ & EN \\
\hline $\begin{array}{l}\text { Senecio doronicum subsp. } \\
\text { glaberrimus Simonkai }\end{array}$ & Vraca & $\mathrm{H}$ & SEM & $\mathrm{S}$ & EN \\
\hline Saxifraga taygetea Boiss. et Heldr. & Vraca/Restelica & $\mathrm{H}$ & Sub-Balkan & $\mathrm{S}$ & EN \\
\hline $\begin{array}{l}\text { Heliosperma nicolicii Niketić \& } \\
\text { Stevanović }\end{array}$ & Vraca & $\mathrm{Ch}$ & Subendemic & $\mathrm{OC}$ & NE \\
\hline Gentianella bulgarica (Vel.) Holab. & Vraca & $\mathrm{T}$ & Balkan & $\mathrm{S}$ & VU \\
\hline Gentiana lutea $\mathrm{L}$. & Vraca/Restelica & $\mathrm{H}$ & SEM & $\mathrm{C} / \mathrm{S} / \mathrm{M}$ & VU \\
\hline Primula halleri J.F.Gmel & Vraca/Restelica & $\mathrm{H}$ & SEEM & $\mathrm{C} / \mathrm{S}$ & VU \\
\hline Atoction lerchenfeldiana Baumg. & Vraca & $\mathrm{H}$ & Balkan & $\mathrm{S}$ & NE \\
\hline Pinguicula balcanica Casper & Vraca & $\mathrm{H}$ & Balkan & $\mathrm{S}$ & NT \\
\hline Sempervivum kosanini Praeger & Vraca & $\mathrm{Ch}$ & SEMM & $\mathrm{S}$ & NT \\
\hline Asperula doerfleri Wettst. & Vraca & $\mathrm{H}$ & Balkan & $\mathrm{S}$ & NT \\
\hline Saxifraga scardica Griseb. & Vraca & $\mathrm{H}$ & Balkan & $\mathrm{S}$ & NT \\
\hline Achillea ageratifolia Sibth. et Sm. & Restelica/Vraca & $\mathrm{Ch}$ & Balkan & $\mathrm{C} / \mathrm{S}$ & NT \\
\hline Campanula alpina Jacq. & Vraca & $\mathrm{H}$ & SEEM & $\mathrm{S}$ & LC \\
\hline Dianthus scardicus Wettst. & Vraca & $\mathrm{H}$ & Balkan & $\mathrm{S}$ & NT \\
\hline Erigeron epiroticus (Vierh) Halacsy & Vraca/Restelica & $\mathrm{H}$ & Sub-Balkan & $\mathrm{S}$ & NT \\
\hline Lilium albanicum Griseb. & Restelica/Vraca & $\mathrm{H}$ & Balkan & $\mathrm{C} / \mathrm{S}$ & LC \\
\hline Aconitum pentheri Hayek & Vraca & $\mathrm{H}$ & Balkan & $\mathrm{C} / \mathrm{S}$ & NE \\
\hline Schiverckia doerfleri (Wettst.) Bornm. & Vraca & $\mathrm{H}$ & SEM & $\mathrm{S}$ & NE \\
\hline $\begin{array}{l}\text { Heliosperma pusilla subsp. albanica } \\
\text { Greuter et Burdet. }\end{array}$ & Vraca & $\mathrm{Ch}$ & Balkan & $\mathrm{C} / \mathrm{S}$ & NE \\
\hline
\end{tabular}

L.F.: Life Form (H - Hemicryptophytes, G - Geophytes, Ch - Chamaephytes, T - Therophytes); Flor. El.: Floral Element (SEMM - South European Mountainous-Mediterranean, CEM - Central European Mountainous, SEM - South European Mountainous, Med - Mediterranean, SEEM - South-East European Mountainous); Sub. Hab.: Substrate and Habitat (OC - Obligate Calculus, S - Siliceous, C - Calcareous, M - Mixed); Status: CR - Critically Endangered, EN - Endangered, LC - Least Concern, NT - Near Threatened, VU - Vulnerable, NE - Not Evaluated. 
The degree of endangerment of these rare species from the impacts of various factors will affect the reduction of their population in the habitat where they grow (Rexhepi 1986).

This paper reviews and discusses the discovery, description, distribution and mapping of two important species for Balkan flora in these localities of the Sharri Mountains - Ranunculus degenii Kümmerle \& Jáv. and Verbascum scardicola Bornm (Fig. 5).

\section{Material and Methods}

Between 2011 and 2016, we carried out annual expeditions during the flowering period (April, May and July) in several floristic expeditions to the Restelica and Vraca valleys within the Sharri Mountains region.

Plant material collection and herbarisation of the newly found $R$. degenii and $V$. scardicola species was performed using classical technique methods (Bunce et al. 2011). The coordinates were recorded using the Garmin eTrex 30 GPS device in the WGS-84 format. During the field expeditions, relevant notes were made on vegetation type and habitat, substrate composition, and the direction in which the species were located (Fig. 2 and Fig. 3). As basic literature for the determination of plant species, we used the Flora Europaea (Tutin et al. 1964, 1980), Flora of Serbia (Josifović 1974), Flora of Macedonia (Micevski 1985-1986), Flora of Greece (Strid \& Tan 1991) and the Flora of Albania vol. 1 (Qosja et al. 1996).

The plants collected in the field were dried and herbarised according to standard procedures.

\section{Results and Discussion}

During the expeditions made between 2011 and 2016 in the Sharri Mountains near Restelica, along the Vraca valley, the presence of two endangered (Balkan) species of limited extent was observed: Ranunculus degenii Kümmerle et Jáv. and Verbascum scardicola Bornm. Both species were found in mixed substrates, siliceous and limestone, at an altitude of 1700-2100 $\mathrm{m}$ above sea level, on the sub-alpine to alpine zone of the Sharri Mountains.

\section{Ranunculus degenii Kümmerle et Jáv.}

New locality: On this new site, we found that the species $R$. degenii was growing in wet or semi-wet meadows, between Restelica and Shishtavec $\left(47^{\circ} 05^{\prime} 41^{\prime \prime} \mathrm{N}\right.$ $46^{\circ} 41^{\prime} 21.7^{\prime \prime} \mathrm{E}, 1815 \mathrm{~m}, 28.04 .2012$; 47010'59' $\mathrm{N} 46^{\circ} 37^{\prime} 64^{\prime \prime} \mathrm{E}, 1742 \mathrm{~m}, 24.05 .2013$ ), which is the second location where this species has been found in Kosovo. The $R$. degenii species is characterised by the fact that the plant's life cycle is not conditioned by the substrate's composition, which means that it is adapted to grow on mixed substrates with different geological rock compositions (Hashani \& Shuka 2012; Hashani et al. 2014). 


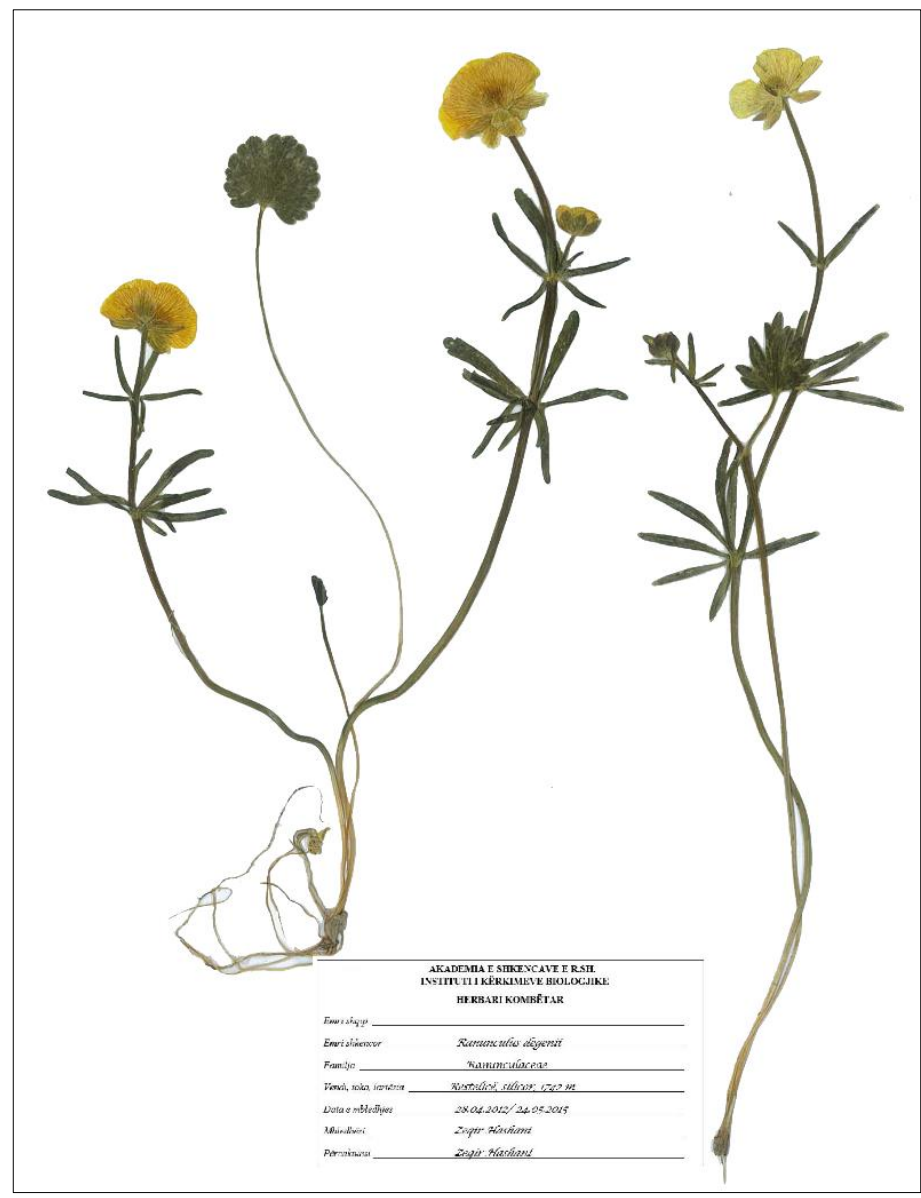

Fig. 1 Herbarium specimens of Ranunculus degenii from the locality of Restelica (photo Z. Hashani).

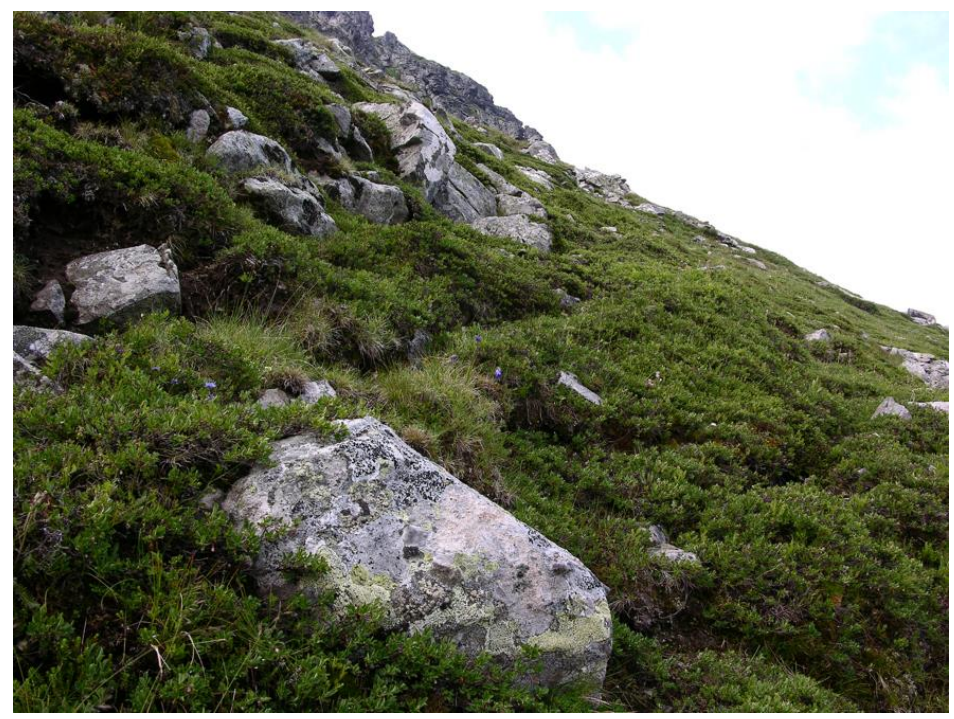

Fig. 2 Ranunculus degenii growth habitat in Restelica valley, Kosovo (photo Z. Hashani, 21.06.2012). 
The species thrives in spring, just after the snow melts, or later in the summer, which is also conditioned by the height of the habitat. During the first expedition in 2011, we encountered it in the growth phase, while during the second expedition in 2013 we encountered it in the full flowering phase (Fig. 1). In Kosovo, thus far the $R$. degenii species has been found in the Albanian Alps (Millaku et al. 2013). Not taking the new location into account, $R$. degenii was rated as a Critically Endangered species in the Red Book of Vascular Flora of Kosovo.

Habitat: In Kosovo, $R$. degenii grows in subalpine to alpine grasslands, at altitudes of $1500 \mathrm{~m}$ to $2250 \mathrm{~m}$, often in wet meadows formed by Pleistocene or earlier depositions (Fig. 2). Typical species that are associated with the growth habituated of these environments include: Parnassia palustris L., Pinguicula sp., Gymnadenia frivaldii Rchb., Eriophorum angustifolium Honck, Cardamine pratensis L., Veratrum sp., and Crocus scardicus Kośanini, as well as the endangered species Galanthus elwesii Hook. f., which was reported for the first time in this study area (Hashani et al. 2019).

Overall spread: The Ranunculus degenni species is found in the Korabi Mountains of Albania (Vangjeli et al. 1995; Rakaj 2009; Shuka \& Malo 2010; Vangjeli 2015) and is also reported to be present in North Macedonia (Micevski 1986; Dunkel 2015). Ranunculus degenii is included in IUCN Global Red List (Walter \& Gillett 1998). Given that this species has very limited distribution in Kosovo, institutions responsible for nature protection should monitor this habitat, which is within the Sharri National Park area.

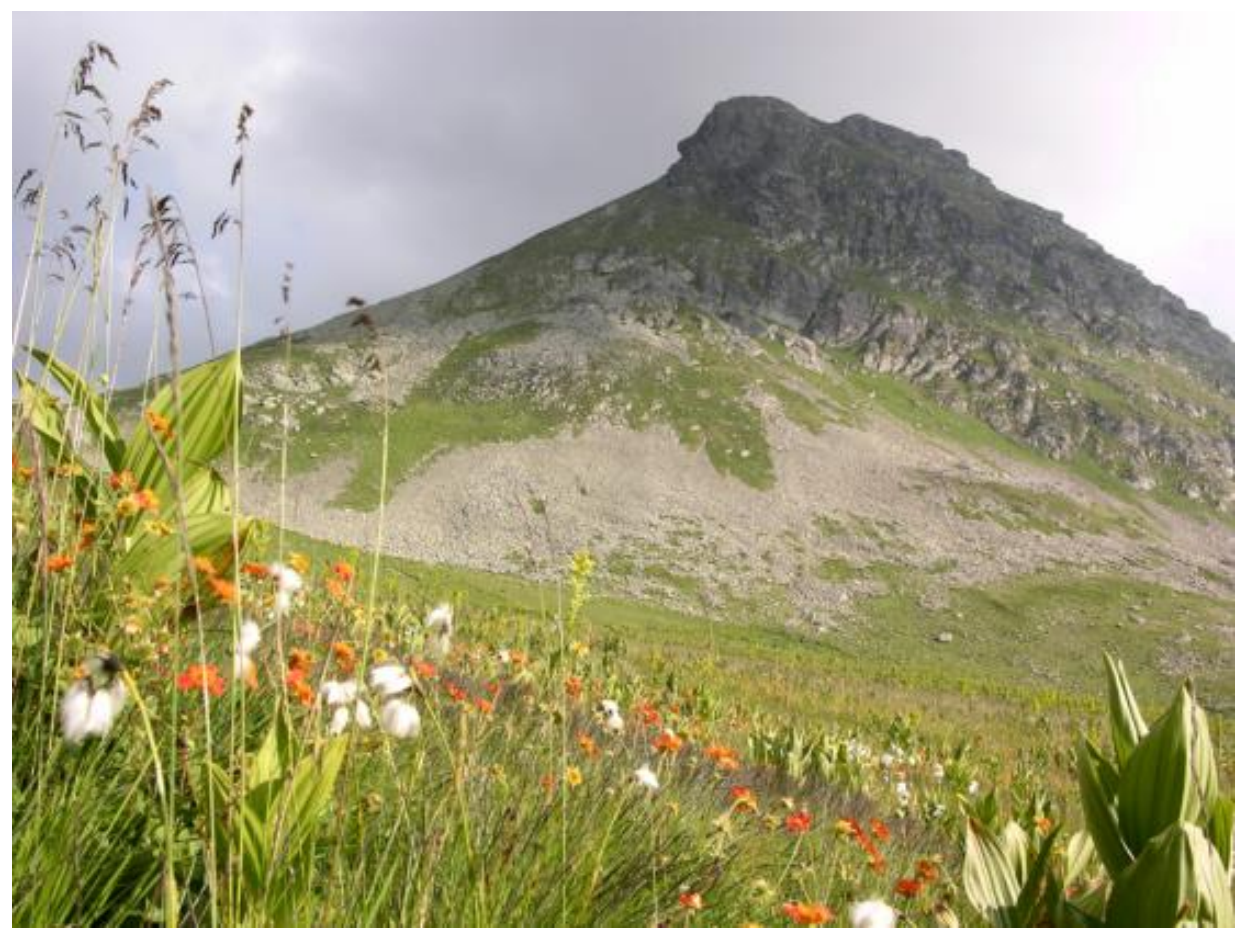

Fig. 3 Growth habitat of Verbascum scardicola in the Vraca valley, Kosovo (12.05.2012). 


\section{Verbascum scardicola Bornm.}

New locality: During the expeditions carried out in 2011, we encountered Verbascum scardicola, an endemic species, reported for the first time in the study area, which is of course important for the flora of Kosovo. It was found in hilly areas in Vraca, mainly in silicate-based rocks. The relevant coordinates are $47^{\circ} 81^{\prime} 12^{\prime \prime} \mathrm{N}$ 46³7'66"'E, 2100 m, 18. 07. 2011 (Fig. 4).

In addition to this locality, this rare species may also grow in other environments and areas, since other authors have described its presence in the limestone substrates of Oshlak and Kobilice within the Sharri Mountains (Josifović 1974; Rexhepi 1986, 2000; Millaku et al. 2013). However, during our expeditions in the Sharri Mountains in the years 2011-2016 we were not able to observe the presence of $V$. scardicola in the Oshlak and Kobilice localities. The population of the Vraca locality is very small (150-200 individuals), and according to the Red Book of Vascular Flora of Kosovo the species is Critically Endangered. This newly discovered habitat of these rare and endangered species constitutes their southernmost edge known to date.

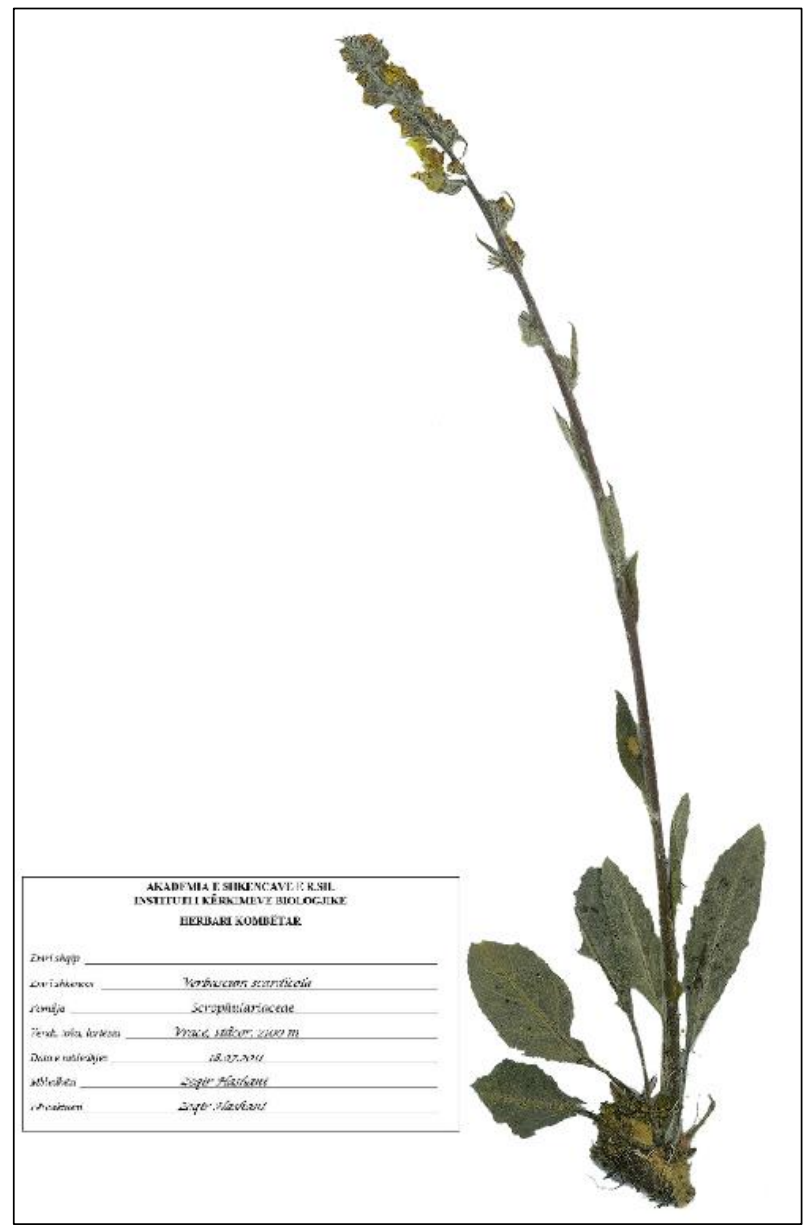

Fig. 4 Herbarium specimen of Verbascum scardicola from the locality of Vraca (photo Z. Hasnani). 
Habitat: Verbascum scardicola in Kosovo grows in the mountain pastures of the alpine area at an altitude of up to $2100 \mathrm{~m}$, which is associated with species typical for these environments, such as Ranunculus montanus Willd., Gentiana punctata L., Potentilla ternata K. Koch, Geum montanum L., Achillea lingulata Waldst. et Kit., Helianthemum alpestre (Jacq.) DC., Campanula alpina Jacq., Nardus stricta L., Juniperus nana Willd., Vaccinium uliginosum L., Polygonum viviparum L., Veronica orsiniana Ten., Ligusticum mutelina L. (Crantz) etc.

The flowering time for $V$. scardicola is in June-July, which is conditioned by the altitude of the habitat (Fig. 3). V. scardicola's life cycle is not conditioned by the substrate's composition, which means it is adapted to grow on mixed substrates with different geological compositions (Naumov et al. 1998).

Overall distribution: The Balkans (Kosovo, Albania and North Macedonia). Since in Kosovo this species is rare and endangered, it has very limited distribution, and therefore the institutions responsible for nature protection should monitor this habitat within the Sharri Mountain area. The taxon is not included in the Red List of European Flora (Bilz et al. 2011), nor is it included in the World Red List (Walter \& Gillett 1998).

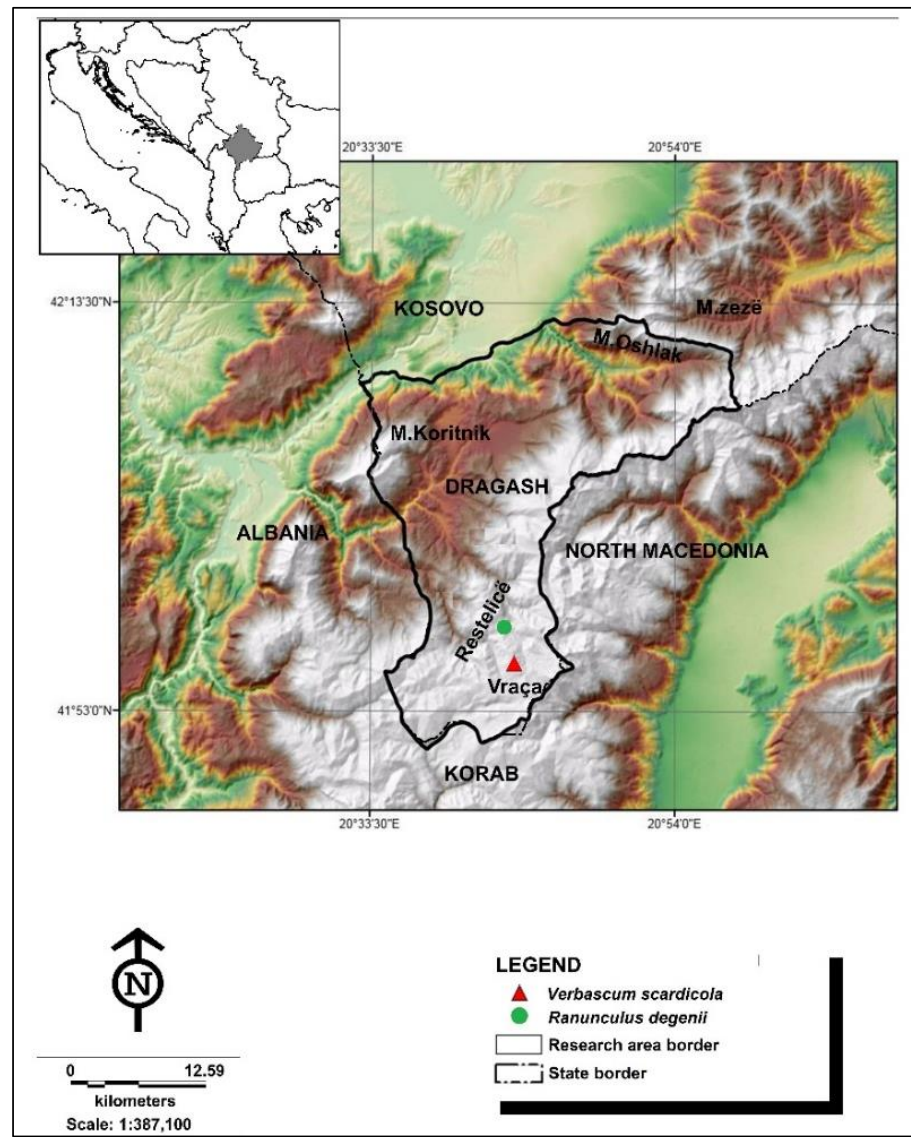

Fig. 5 Distribution of Verbascum scardicola and Ranunculus degenii in Kosovo. 


\section{Conclusions}

Ranunculus degenii and Verbascum scardicola have been recorded for the first time in these localities in the Sharri National Park, albeit with very limited distribution, in subalpine and alpine pastures. The locations of both species are not dependent on the substrate, and we propose to monitor the species and the habitats where they grow.

These species, found and identified in the cross-border territory between Kosovo, Albania and North Macedonia (the valleys of Restelica and Vraca), indicate the possibility of finding other rare and endemic species of flora in that area. Given that the number of rare-endemic species that grow in these surveyed areas of Kosovo should be higher, it is necessary to have action plans for their protection. It is also important for floristic studies in the area to continue so that a full inventory of the country's flora can be made.

\section{References}

Anonymous (2008): Preliminary identification of Natura 2000 Areas. - MESP, Prishtina, Kosovo.

Bilz M., Kell S. P., Maxted N. \& Lansdown R. V. (2011): European Red List of Vascular Plants. - Luxembourg: Publications Office of the European Union. 130 pp. doi:10.2779/8515

Bunce R. G. H., Bogers M. M. B., Roche P., Walczak M., Geijzendorffer I. R. \& Jongman R. H. G. (2011): Manual for Habitat and Vegetation Surveillance and Monitoring: Temperate, Mediterranean and Desert Biomes. First edition. - Wageningen, Alterra, Alterra report 2154. $106 \mathrm{pp}$.

Dunkel F. G. (2015): Ranunculus pindicola sp. nov., the only species of the $R$. auricomus complex (Ranunculaceae) in Greece. - Willdenowia 45/2: 223-230. doi.org/10.3372/wi.45.45208

Hashani Z. \& Shuka L. (2012): Distribution and conservation status of Primula halleri and Ranunculus incomparabilis species in Kosovo. - Proceedings of Balwois, Ohrid, Macedonia.

Hashani Z., Maxhuni Q. \& Shuka L. (2014): Distribution of plant species of the Koritnik and Brod Mts. based on substrate preference. - BSHN (UT), 18: 25-37. [In Albanian]

Hashani Z., Maxhuni Q., Ferizi R., Abdurrahman A. \& Mala Xh. (2019): Galanthus elwesii Hook (Amaryllidaceae) in the flora of Kosovo. - Hacquetia 18/1: 137-142. DOI: 10.2478/hacq2018-0012

Hoxha V., Mekshiqi N., Hoxha J., Kodra A., Dardha M., Hysenaj R., Fejza I,. Avdullahu S., Meha M., Çadraku H., Sahiti F. \& Dardha A. (2009): Geological correlations of the Kosovo-Albania border area. - Plansheti K-34-78-A, Shishtaveci. - Ministry of Energy and Mining, Prishtina. 65 pp. [in Albanian].

ICMM. (2006): Geological map of Kosovo. Scale 1:200,000. - The independent commission for mines and minerals. - Prishtine, Kosovo.

Josifović M. (1974): Flora SR Srbije. Vol. VI. - Beograd. pp 109. [in Serbian].

Maxhuni Q., Morina I., Morina R., Ferizi R. \& Hashani Z. (2014): Biodiversity and protected areas in Kosovo. - Int. J. ecosyst. ecol. sci. 4(1): 173-178.

Micevski K. (1985): The Flora of the Republic of Macedonia. - MANU, Skopje. 136 pp. [In Macedonian] 
Micevski K. (1986): Prilog kon taksonomijata i horologijata na taksonot Ranunculus degenii Küemm. et Jav. vo florata na SR Makedonija. - Prilozi, Odd. biol. med. nauki, MANU 5(1): 5-9. [In Macedonian].

Millaku F., Rexhepi F., Krasniqi E., Pajazitaj Q., Mala Xh. \& Berisha N. (2013): The Red Book of Vascular Flora of the Republic of Kosovo. - Prishtine. $435 \mathrm{pp}$.

Naumov P., Kuzmanovski I. \& Stefanova M. (1998): Flavonoides of Verbascum scardicolum and Melampyrum scardicum. - Bull. Chem. Technol. Macedonia 17/1: 41-44.

Qosja Xh., Paparisto K., Vangjeli J. \& Ruci B. (1996): Flora of Albania. Vol. 3. - Albanian Academy of Sciences, Center for Biological Research. - Tirana, Albania. 331 pp. [in Albanian].

Rakaj M. (2009): Floristic and chorological news from north Albania. - Bot. Serb. 33(2): 177183.

Rexhepi F. (1986): Flora of higher mountains of Kosovo. - Authority of textbooks and teaching in Kosovo, Prishtina. p. 102-103. [in Albanian].

Rexhepi F. (2000): Endemic plants of Kosovo. - University of Prishtina, Prishtina. 4-129.

Shuka L., Kashta L. \& Xhulaj M. (2008): Evaluation of potential transboundary important plant areas of the North Albania. - Nat. Montenegrina 7/3: 425-439.

Shuka L. \& Malo S. (2010): The transboundary important plant areas as conservation units of European green belt (Eastern Albanian zone). - J. Environ. Prot. Ecol. 11/3: 866-874.

Stefanović V., Tan K. \& Latrou G. (2003): Distribution of the endemic Balkan flora on serpentine I. - obligate serpentine endemics. - Plant Syst. Evol. 242/1: 149-170. DOI: 10.1007/s00606-003-0044-8

Strid A. \& Tan K. (1991): Mountain flora of Greece. - Cambridge University Press. 2: 1-970.

Tutin T. G., Heywood V. H., Burges N. A., Moore D. M., Valentine D. H., Walters S. M. \& Webb D. A. (1964-1980): Flora Europaea. Vol. 1-5, - Cambridge University Press.

Vangjeli J., Ruci B. \& Mullaj A. (1995): The Red Book of Albania. Endangered and rare plants. Academy of Science. Tirana, Albania, pp: 1 - 165. [in Albanian].

Vangjeli J. (2015) Excursion Flora of Albania. - Koeltz Botanical Books, Oberreifenberg. 661 pp.

Väre H., Lampinen C., Humphries C. \& Williams P. (2003): Taxonomic diversity of vascular plants in the European alpine areas. - In: Nagy L., Grabherr G., Körner C., Thompson D. B. A., Alpine biodiversity in Europe. - Springer-Verlag. pp.: 133-148.

Walter K. S. \& Gillett H. J. (1998): 1997 IUCN Red List of Threatened Plants. IUCN, Gland, Switzerland and Cambridge, UK. 